\title{
EFFECTS OF LIGHT THERMAL TREATMENTS ON THE COLOR, HYGROSCOPITY AND DIMENSIONAL STABILITY OF WOOD
}

\author{
Xin You Liu, Xin Wei Tu, Mihaela Liu \\ Nanjing Forestry University \\ China
}

(Received March 2020)

\begin{abstract}
Ailanthus wood (Ailanthus desf.) was thermally treated at three different low temperatures $\left(140,160,180^{\circ} \mathrm{C}\right)$ for 2 and $4 \mathrm{~h}$ in order to investigate the effects on wood color, hygroscopity and dimensional stability. Results indicate that mass loss increased following the treatments, while equilibrium moisture content decreased from $11.86 \%$ to $9.88 \%$ for the $180^{\circ} \mathrm{C}$ and $4 \mathrm{~h}$ treatment. Moreover, improvements in the dimension stability were observed for post-treatment samples. The thermal treatment induced color changes in the Ailanthus wood, with a significant reduction in the lightness, yet the redness and yellowness exhibited minimal changes. FITR spectra of the thermally treated wood suggest that the heat treatment resulted in the deacetylation of hemicellulose. These results help to conclude that thermal treating temperature under $160^{\circ} \mathrm{C}$ can improve wood dimensional stability and maintain original color.
\end{abstract}

KEYWORDS: Thermal modification, Ailanthus wood, color change, dimensional stability.

\section{INTRODUCTION}

Wood is an essential renewable material, with an excellent strength to weight ratio, is easy to process, has excellent environmental characteristics and is widely used in construction engineering and interior design (He et al 2019, Percin et al. 2016). However, due to the dry shrinkage and wet swelling of wood, its use is often limited (Okon et al. 2017, Korkut and Hiziroglu 2014, Kasemsiri et al. 2012). Common methods of wood modification include impregnation resin, acetylation and high-temperature thermal treatments (Candan et al. 2013, Esteves et al. 2011, Esteves et al. 2007a, 2007b, 2008). In particular, high-temperature thermal treatment is an environmentally friendly modification method, which can degrade hemicellulose and lignin and reduce hydrophilic groups in wood. It can also increase the crystallization zone and crystallinity of cellulose, thus reducing wood hygroscopicity and improving the dimensional stability (Esteves and Pereira 2009). 
The heat treatment of wood, also known as wood thermal modification, is defined by the European standard (CEN/TS 15679:2007) as follows: At a temperature higher than $160^{\circ} \mathrm{C}$ in a hypoxia environment, inducing changes in the cell wall composition and physical properties of the wood. The extent of the changes in wood properties during the thermal treatment is a function of the processing method, the wood species and, the initial moisture content of the wood, the ambient atmosphere and the treatment duration and temperature (Yildiz et al. 2006). Temperature has a greater impact on the thermal wood properties compared to the treatment time, and prolonging the treatment time does not result in the same effects as treating with a higher temperature (Korkut and Guller 2008). Compared with unmodified wood, thermal treated wood exhibits a lower EMC (equilibrium moisture content) (Santos et al. 2014, Zhou et al. 2013, Obataya et al. 2000) and smoother contact surfaces (Unsal and Ayrilmis 2005). The thermal treating of wood has been observed to lead to a darkening in color. For example, Esteves found that pine (Pinus pinaster) and eucalyptus (Eucalypt globule) wood became darker, with the lightness reduced by $50 \%$ following heat treatment with hot air or steam over a period of $2-24 \mathrm{~h}$ above $170^{\circ} \mathrm{C}$ (Esteves et al. 2007b). The dimensional stability of the wood often requires improvement while maintaining the original color. The color changes of thermal wood can be compensated via two techniques: thermally treating wood in a vacuum environment (Sivrikaya et al. 2019) and thermally treating under lower temperatures. In this study, the wood of Ailanthus (Ailanthus desf.) was treated at several temperatures of $140-180^{\circ} \mathrm{C}$ improvement while maintain hygroscopicity and dimensional stability were tested to explore a thermal treatment process that could improve the dimensional stability and maintain the original color.

\section{MATERIAL AND METHODS}

\section{Sample preparation}

Ailanthus (Ailanthus desf.), a white colored wood with a similar grain to white oak that is commonly cultivated in China, was sourced from Sichuan Province, China. The test specimens were prepared from sapwood with dimensions of $20 \times 20 \times 20 \mathrm{~mm}$ (length $\times$ width $\times$ thickness) and an initial moisture content of $70 \pm 5 \%$ (according to the GB/T 1931-2009 standard) (Zhao et al. 2009). All specimens were dried at $103^{\circ} \mathrm{C}$.

\section{Thermal treatment}

Thermal treatments were conducted in an oven at the temperatures of $140^{\circ} \mathrm{C}, 160^{\circ} \mathrm{C}$ and $180^{\circ} \mathrm{C}$ for 2 and $4 \mathrm{~h}$. A control group of samples was left untreated (denoted as $20^{\circ} \mathrm{C}$ ) and compared to the thermally modified samples.

\section{Mass percentage loss (MPL)}

The MPL was determined based on variations in the mass before and after the thermal treatment as follows:

$$
\text { MPL }=\frac{m_{0}-m_{t}}{m_{0}} \times 100 \%
$$

where: $\mathrm{m}_{0}$ is the pre-treatment oven-dried weight of the specimen $(\mathrm{g})$ and $\mathrm{m}_{\mathrm{t}}$ denotes the post-treatment weight of the same specimen $(\mathrm{g})$. 


\section{Wood dimensional stability estimations}

Swelling tests were performed according to the GB/T 1931-2009 standard (Zhao et al. 2009). The treated and control groups were oven dried and subsequently stored in a climate controlled chamber at $20^{\circ} \mathrm{C}$ with $65 \%$ humidity in order to reach EMC. The dimensions and weights of the specimens were measured before and after conditioning. The swelling coefficient was calculated as follows (Zhao et al. 2009):

$$
a=\frac{l_{w}-l_{0}}{l_{0}} \times 100 \%
$$

where: $\mathrm{a}$ is the swelling coefficient (radial, tangential or longitudinal), $1_{0}$ denotes the initial dimension of the specimen, and $1_{w}$ represents the dimension after conditioning.

\section{Moisture absorption (MA)}

The process used to determine the MA is detailed as follows. The specimens were placed in a chamber with a constant temperature of $20^{\circ} \mathrm{C}$ and $65 \%$ humidity to reach the EMC according to the GB/T 1931-2009 standard (Zhao et al. 2009). Following conditioning in the climate chamber, the MA was calculated via Eq. (3):

$$
M A=\frac{w_{a}-w_{b}}{w_{b}} \times 100 \%
$$

where: $\mathrm{w}_{\mathrm{b}}\left(\mathrm{w}_{\mathrm{a}}\right)$ denotes the weight of the specimens before (after) conditioning in the climate chamber $(\mathrm{g})$.

\section{Color measurements}

Pre- and post-treatment surface color measurements of all specimens on the tangential section were collected using an AvaSpec-USB2 spectrometer (Avante, Netherlands) equipped with an integrating AVA sphere with a diameter of $80 \mathrm{~mm}$. Measurements were made using a D65 standard illuminant and a $10^{\circ}$ standard observer. The reflectance percentage, collected at $10 \mathrm{~nm}$ intervals over the visible spectrum $(400-700 \mathrm{~nm})$ was converted into the CIELAB color system. The resultant pre- and post-treatment colour coordinates were lightness L* (from 0 for black to 100 for white), redness a* (from negative values for green to positive values for red on the green-red axis) and yellowness $b^{*}$ (from negative values for blue to positive values for yellow on the blue-yellow axis). Colour differences between treated and control samples were calculated based on Eq. (4):

$$
\Delta \mathrm{E}=\sqrt{\Delta L^{* 2}+\Delta a^{* 2}+\Delta b^{* 2}}
$$

where: $\Delta \mathrm{L}^{*}, \Delta \mathrm{a}^{*}$ and $\Delta \mathrm{b}^{*}$ are the differences of the pre- and post-treatment values of $\mathrm{L}^{*}, \mathrm{a}^{*}$ and $\mathrm{b}^{*}$, respectively. Low $\Delta \mathrm{E}$ values correspond to a small colour difference.

\section{Chemical structure analysis}

ATR-IR spectra of the control and thermally modified wood milled samples were collected using a standard FTIR spectrometer (Tensor 27, Bruker, Germany) via direct transmittance at a resolution of $4 \mathrm{~cm}^{-1}$ for 32 scans across $700-4000 \mathrm{~cm}^{-1}$. The alignment of the light equipment and the background spectra was performed before the measurements began. The spectra were averaged over 6 measurements for each treatment. 


\section{RESULTS AND DISCUSSION}

\section{Mass percentage loss}

The MPL is a key indicator for the quality of thermally treated wood. In particular, it is a function of wood species, heating medium, temperature and treatment time (Esteves and Pereira 2009). Tab. 1 reports the mass loss of the treated samples. The results indicate that mass loss increased with temperature. More specifically, under the $180^{\circ} \mathrm{C}$ and $4 \mathrm{~h}$ heat treatment, the mass loss was observed as $2.437 \%$, which is greater than the equivalent value for $140^{\circ} \mathrm{C}(1.432 \%)$. Moreover, the mass loss also increased with treatment duration. At $160^{\circ} \mathrm{C}$, the mass loss was observed to be $1.395 \%$ and $1.734 \%$ under $2 \mathrm{~h}$ and $4 \mathrm{~h}$, respectively.

Tab. 1. Mass loss of the thermally treated wood.

\begin{tabular}{|c|c|c|c|}
\hline Wood sp. & Treatment & Initial mass (g) & Mass loss (\%) \\
\hline Ailanthus & $140^{\circ} \mathrm{C}, 2 \mathrm{~h}$ & 4.024 & $0.761(0.071)$ \\
\hline Ailanthus & $140^{\circ} \mathrm{C}, 4 \mathrm{~h}$ & 4.139 & $1.432(0.112)$ \\
\hline Ailanthus & $160^{\circ} \mathrm{C}, 2 \mathrm{~h}$ & 4.265 & $1.395(0.094)$ \\
\hline Ailanthus & $160^{\circ} \mathrm{C}, 4 \mathrm{~h}$ & 4.035 & $1.734(0.083)$ \\
\hline Ailanthus & $180^{\circ} \mathrm{C}, 2 \mathrm{~h}$ & 4.126 & $1.962(0.132)$ \\
\hline Ailanthus & $180^{\circ} \mathrm{C}, 4 \mathrm{~h}$ & 4.135 & $2.437(0.048)$ \\
\hline
\end{tabular}

*Values in parentheses indicate standard deviation.

\section{Wood dimensional stability and moisture absorption}

Wood dimensional stability has a significant influence on the quality and usage of wood products. The swelling coefficients in the tangential and radial directions are the most influential factors for wood dimensional stability estimations. Fig. 1 demonstrates the influence of the thermal treatments on wood dimensional stability.

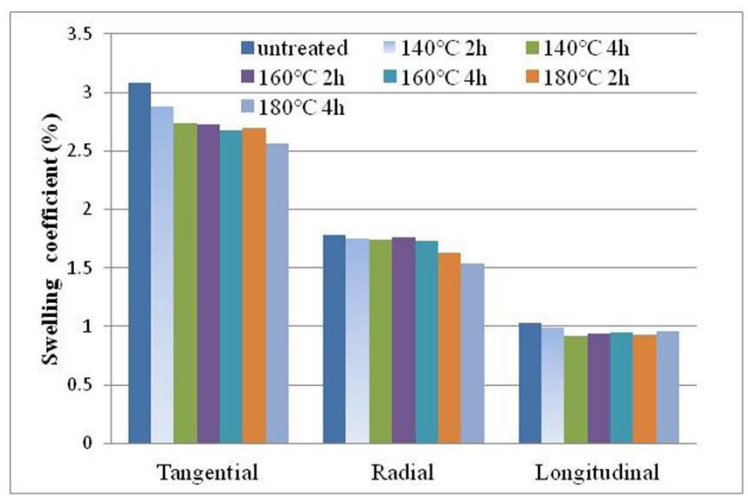

Fig. 1. Swelling coefficients in the tangential, radial and longitudinal directions for the treatment and control groups.

The average value of the swelling coefficient of the control group was 3.08\%,1.78\% and $1.03 \%$ in the tangential, radial and longitudinal sections, respectively. Following the $180^{\circ} \mathrm{C} 4 \mathrm{~h}$ treatment and compared with the control group, the swelling coefficient decreased by $16.88 \%$ in 
the tangential section, with a smaller reduction of $6.80 \%$ in the longitudinal section. Compared with the control group, all three swelling coefficient decreased with increasing treatment temperature and duration. The results demonstrate that the thermal treatments markedly decreased the wood swelling coefficients in the tangential and radial directions, with less of an impact on the wood swelling coefficients in the longitudinal direction. This may be attributed to the ease of shrinking and swelling of wood in the tangential and radial directions, with a greater stability in the longitudinal direction (Liu and Zhao 2012). The increase of wood dimensional stability via the thermal treatment is a result of the hydrophilic substances degradation induced by higher temperatures (Esteves and Pereira 2009).

\section{Moisture absorption}

Wood moisture content under the fiber saturation point (FSP) has been demonstrated to have a great impact on wood dimensional stability. To further investigate the effects of thermal treatment on wood dimensional stability, MA was recorded as an indicator for wood hygroscopicity. Tab. 2 reports the MA values for the specimens before and after conditioning in the climate chamber at a temperature of $20^{\circ} \mathrm{C}$ with $65 \%$ humidity. The average mass of the untreated specimens pre- and post-conditioning varied from 4.036 to $4.507 \mathrm{~g}$, with an MA of approximately $11.68 \%$. Furthermore, the MA for the treated group was observed to decrease compared with the control group. Thus, the thermal treatments markedly decreased the MA ability of the wood samples, and can therefore be applied to increase wood dimensional stability.

Tab. 2. MA of untreated and thermally treated wood.

\begin{tabular}{|c|c|c|c|c|}
\hline Wood sp. & Treatment & $\begin{array}{c}\text { Pre-conditioning } \\
\text { mass (g) }\end{array}$ & $\begin{array}{c}\text { Post-conditioning } \\
\text { mass (g) }\end{array}$ & MA (\%) \\
\hline Ailanthus & untreated & 4.036 & 4.507 & 11.682 \\
\hline Ailanthus & $140^{\circ} \mathrm{C}, 2 \mathrm{~h}$ & 3.993 & 4.443 & 11.263 \\
\hline Ailanthus & $140^{\circ} \mathrm{C}, 4 \mathrm{~h}$ & 3.992 & 4.427 & 10.895 \\
\hline Ailanthus & $160^{\circ} \mathrm{C}, 2 \mathrm{~h}$ & 3.987 & 4.427 & 11.048 \\
\hline Ailanthus & $160^{\circ} \mathrm{C}, 4 \mathrm{~h}$ & 3.972 & 4.374 & 10.127 \\
\hline Ailanthus & $180^{\circ} \mathrm{C}, 2 \mathrm{~h}$ & 3.946 & 4.339 & 9.979 \\
\hline Ailanthus & $180^{\circ} \mathrm{C}, 4 \mathrm{~h}$ & 3.897 & 4.282 & 9.883 \\
\hline
\end{tabular}

\section{Post-treatment color changes}

Ailanthus cultivated in China, used for furniture making, has white color. The values of the coordinates $\mathrm{L}^{*}, \mathrm{a} *, \mathrm{~b}$ * of untreated wood are 76.97, 5.96 and $27.48 . \Delta \mathrm{L}^{*}$ values were negative, indicating a darker color for the wood following the heat treatment via the reduced lightness due to higher temperatures during the heating process. The blackish hue increased for temperatures within $140-180^{\circ} \mathrm{C}$. For example, the lightness value $\left(\mathrm{L}^{*}\right)$ decreased from 76.97 to 64.53 for the samples exposed to the $180^{\circ} \mathrm{C}$ heat treatment for $4 \mathrm{~h}$. However, for the same treatment duration under $140^{\circ} \mathrm{C}$, L* decreased from 77.20 to 75.88 . Esteves et al. (2007b) observed a reduction in $\mathrm{L}^{*}$ for transverse sections of pine by $9.4 \%$ and $28.4 \%$ for $2 \mathrm{~h}$ at 170 and $200^{\circ} \mathrm{C}$, respectively. The values of $\mathrm{a}^{*}$ and $\mathrm{b}^{*}$ slightly increased following the thermal treatment by 4.34 unit for $\Delta \mathrm{a}^{*}$ and 5.42 unit for $\Delta \mathrm{b}^{*}$ under the $180^{\circ} \mathrm{C} 4 \mathrm{~h}$ treatment. Comparing the color change from these six thermal treatment processes, $140^{\circ} \mathrm{C}(2$ and 4 hours $)$ and $160^{\circ} \mathrm{C}(2$ hours $)$ can maintain original color better than other processes. 


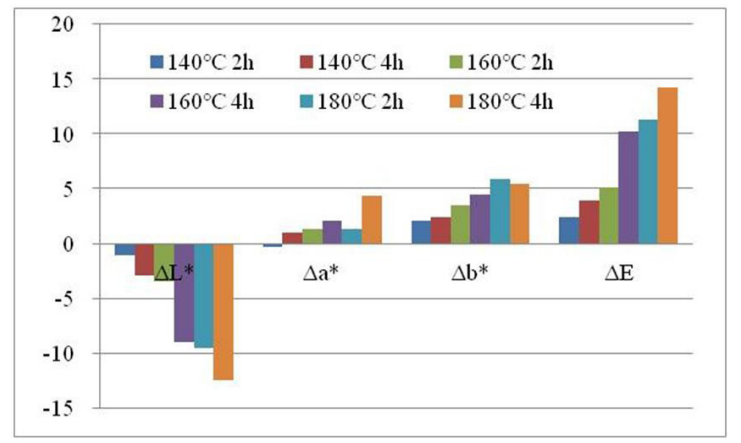

Fig. 2. Changes in $L^{*}, a^{*}$ and $b^{*}$ and the total color change $(\Delta E)$ for thermally treated samples.

\section{Chemical structure analysis}

The dimensional stability of wood is directly linked to the hydroxyl $(-\mathrm{OH})$ and other chemical contents, and can result in changes in, or the loss of, hydroxyl or other chemical groups that play key roles in the stability of wood (He et al. 2016, Jiang et al. 2015, Mitani and Barboutis 2014). FTIR spectroscopy is able to effectively measure variations in the chemical structure of samples resulting from different treatments (Basso et al. 2017, He et al. 2017, Chen et al. 2011). The FTIR spectra in the range of $800-1800 \mathrm{~cm}^{-1}$ for the treated samples at $140^{\circ} \mathrm{C}, 160^{\circ} \mathrm{C}$ and $180^{\circ} \mathrm{C}$ under 4 hours and the control group are displayed in Fig. 3.

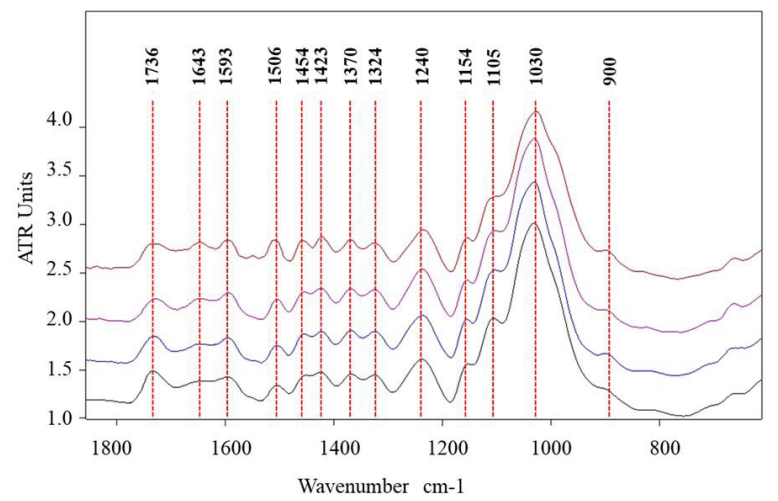

Fig. 2. Comparative FTIR spectra of untreated and thermal treated wood samples in the range of $800-1800 \mathrm{~cm}^{-1}$ (from bottom to top: untreated, $140^{\circ} \mathrm{C}, 160^{\circ} \mathrm{C}$ and $180^{\circ} \mathrm{C}$ ).

To compare the spectra of the untreated and heat-treated samples, all spectra were normalized to the $\mathrm{C}-\mathrm{H}$ aliphatic stretching peak at $2905 \mathrm{~cm}^{-1}$ (Kocaefe et al. 2008). Although the chemical structures of the thermally treated specimens were modified compared to the control, the changes were minimal. The band intensities at $1736 \mathrm{~cm}^{-1}$ were observed to decrease, corresponding to the stretching of the carbonyl groups of acetyls in hemicellulose (Chien et al. 2018). This indicates that the heat treatment resulted in the deacetylation of hemicellulose by the cleavage of the acetyl groups (Altgen et al. 2018a,b). The absorption band at $1643 \mathrm{~cm}^{-1}$ assigned to conjugated carbonyl groups, were observed to increase, especially after $180^{\circ} \mathrm{C}$ thermal 
treatment 4 hours. This suggests that more conjugated/aromatic carbonyl groups were formed during thermal treatment. In addition, aromatic skeletal stretching bands in lignin were observed at $1593 \mathrm{~cm}^{-1}$. The intensities of these bands increased with the heat treatment temperature. This is attributed to the increase of the relative percentage of lignin due to polysaccharide degradation, and in particular, hemicellulose degradation. An additional characteristical band for aromatic ring stretching appeared at approximately $1506 \mathrm{~cm}^{-1}$, which also exhibited an increasing intensity with thermal temperatures. This can be explained by the thermal decomposition of the syringyl moiety of lignin. In addition, the band corresponding to $\mathrm{C}-\mathrm{O}$ stretching at $1105 \mathrm{~cm}^{-1}$ appeared to be significant for the $180^{\circ} \mathrm{C}$ heat treatment. This may correspond to the formation of an ether linkage from the hydroxyl groups within hemicelluloses and lignin (Colom et al. 2003), or to the formation of new alcohols and esters (Kocaefe et al. 2008) during the heat treatment.

\section{CONCLUSIONS}

In the current study, wood from the Ailanthus tree genus was thermally modified at $140^{\circ} \mathrm{C}, 160^{\circ} \mathrm{C}$ and $180^{\circ} \mathrm{C}$ for 2 and $4 \mathrm{~h}$. In particular, we investigated the mass loss, swelling coefficient, moisture absorption, color change and variations in FITR spectra of the treated wood compared to the control group. Following the thermal treatment, mass loss increased, while EMC was significantly reduced with increasing treatment temperature and duration. Furthermore, the dimension stability was improved with the thermal treatment. Changes in the color of the Ailanthus wood were induced by the thermal treatment, however changes in the redness and yellowness were limited. Permutations in the FITR spectra of the thermal treated wood compared to the control suggest that the heat treatment results in the deacetylation of hemicellulose. According to the results of color change and dimensional stability and moisture absorption, $160^{\circ} \mathrm{C}$ for $2 \mathrm{~h}$ can improve wood dimensional stability well and maintain original color.

\section{ACKNOWLEDGMENTS}

This work was supported by the Nanjing Forestry University Foundation for Basic Research (Grant No. 163104127) and the Priority Academic Program Development (PAPD) of Jiangsu Province, China.

\section{REFERENCES}

1. Altgen, M., Uimonen, T., Rautkari, L., 2018: The effect of de- and re-polymerization during heat-treatment on the mechanical behavior of Scots pine sapwood under quasi-static load. Polymer Degradation and Stability 147: 197-205.

2. Altgen, M., Willems, W., Hosseinpourpia, R., Rautkari, L., 2018: Hydroxyl accessibility and dimensional changes of Scots pine sapwood affected by alterations in the cell wall ultra structure during heat-treatment. Polymer Degradation and Stability 152: 244-252

3. Basso, M.C., Pizzi, A., Polesel Maris, J., Delmotte, L., Colin, B., Rogaume, Y., 2017: MALDI-TOF, 13C NMR and FTIR analysis of the cross-linking reaction of condensed tannins by triethyl phosphate. Industrial Crops and Products 95: 621-631. 
4. Candan, Z., Korkut, S., Unsal, O., 2013: Effect of thermal modification by hot pressing on performance properties of paulownia wood boards. Industrial Crops and Products 45: 461-464.

5. CEN/TS15679, 2007: Thermal modified timber - definitions and characteristics.

6. Chen, W., Yu, H., Liu, Y., Chen, P., Zhang, M., Hai, Y., 2011. Individualization of cellulose nanofibers from wood using high-intensity ultrasonication combined with chemical pretreatments. Carbohydrate Polymers 83(4): 1804-1811.

7. Chien, Y., Yang, T., Hung, K., Li, C., Xu, J., Wu, J., 2018: Effects of heat treatment on the chemical compositions and thermal decomposition kinetics of Japanese cedar and beech wood. Polymer Degradation and Stability $158: 220-227$.

8. Chinese Standard: GB/T 1931, 2009: Method for determination of the moisture content of wood.

9. Colom, X., Carrillo, F., Nogues, F., Gaariga, P., 2003: Structural analysis of photodegraded wood by means of FTIR spectroscopy. Polymer Degradation and Stability 80: 543-549.

10. Esteves, B., Domingos, I., Pereira, H., 2007a: Improvement of technological quality of eucalypt wood by heat treatment in air at $170-200^{\circ} \mathrm{C}$. Forest products journal $57(1-2)$ : 47-52.

11. Esteves, B., Marques, A.V., Domingos, I., Pereira, H., 2007b: Influence of steam heating on the properties of pine (Pinus pinaster) and eucalypt (Eucalyptus globulus) wood. Wood Science and Technology 41(3): 193-207.

12. Esteves, B., Graça, J., Pereira, H., 2008: Extractive composition and summative chemical analysis of thermally treated eucalypt wood. Holzforschung 62(3): 344-351.

13. Esteves, B., Pereira, H., 2009: Wood modification by heat treatment. A review. BioResources 4(1): 340-404.

14. Esteves, B., Videira, R., Pereira, H., 2011. Chemistry and ecotoxicity of heat-treated pine wood extractives. Wood Science and Technology 45(4): 661-676.

15. He, Z., Zhang, Y., Wang, Z., Zhao, Z., Yi, S., 2016: Reducing wood drying time by application of ultrasound pretreatment. Drying Technology 34: 1141-1146.

16. He, Z., Wang, Z., Zhao, Z., Yi, S., Mu, J., Wang, X., 2017: Influence of ultrasound pretreatment on wood physiochemical structure. Ultrasonics Sonochemistry 34: 136-141.

17. He, Z., Qian, J., Qu, L., Yan, N., Yi, S., 2019: Effects of tung oil treatment on wood hygroscopicity, dimensional stability and thermostability. Industrial Crops and Products 140: 111647.

18. Jiang, J., Li, J., Gao, Q., 2015. Effect of flame retardant treatment on dimensional stability and thermal degradation of wood. Construction and Building Materials 75: 74-81.

19. Kasemsiri, P., Hiziroglu, S., Rimdusit, S., 2012: Characterization of heat treated eastern red cedar (Juniperus virginiana L.). Journal of Materials Processing Technology 212(6): 1324-1330.

20. Kocaefe, D., S. Poncsak, Y. Boluk, 2008: Effect of thermal treatment on the chemical composition and mechanical properties of birch and aspen. BioResources 3(2): 517-537.

21. Korkut, D.S., Guller, B., 2008: The effects of heat treatment on physical properties and surface roughness of red-bud maple (Acer trautvetteri Medw.) wood. Bioresource Technology 99(8): 2846-2851

22. Korkut, D., Hiziroglu, S., 2014: Experimental test of heat treatment effect on physical properties of red oak (Quercus falcate michx.) and southern pine (Pinus taeda L.). Materials 7(11): 7314-7323.

23. Liu, Y.X., Zhao, G.J., 2012: Wood Science. China Forestry Press, Beijing Pp 125-134. 
24. Mitani, A., Barboutis, I., 2014: Changes caused by heat treatment in colour and dimensional stability of beech (Fagus sylvatica L.) wood. Drvna Industrija 65: 225-232.

25. Obataya, E., Tanaka, F., Norimoto, M., Tomito, B., 2000: Hygroscopicity of heat-treated wood 1. Effects of after treatments on the hygroscopicity of heat-treated wood. Journal of the Japan Wood Research Society 46(2): 77-87.

26. Okon, K.E., Lin, F., Chen, Y., Huang, B., 2017: Effect of silicone oil heat treatment on the chemical composition, cellulose crystalline structure and contact angle of Chinese parasol wood. Carbohydrate Polymers 164: 179-185.

27. Percin, O., Perker, H., Atilgan, A., 2016: The effect of heat treatment of the some physical and mechanical properties of beech (Fagus orientalis Lipsky) wood. Wood Research 61(3): 443-456.

28. Santos, D.V.B.D., Mouora, L.F.D., Brito, J.O., 2014: Effect of heat treatment on color, weight loss, specific gravity and equilibrium moisture content of two low market valued tropical wood. Wood Research 59(2): 253-264.

29. Sivrikaya, H., Tesařová, D., Jeřábková, E. , Can, A., 2019: Color change and emission of volatile organic compounds from Scots pine exposed to heat and vacuum-heat treatment. Journal of Building Engineering 26: 100918.

30. Unsal, O., Ayrilmis, N., 2005: Variations in compression strength and surface roughness of heat-treated Turkish river red gum (Eucalyptus camaldulensis) wood. Journal of Wood Science 51(4): 405-409.

31. Yildiz, S., Gezer, E.D., Yildiz, U.C., 2006: Mechanical and chemical behavior of spruce wood modified by heat. Building and Environment 41(12): 1762-1766.

32. Zhou, Q.F., Tu, D.Y., Liao, L., Guo, Q. 2013: Variation of equilibrium moisture content of heat-treated Couratari oblongifolia, Fraxinus excelsior and Quercus rubra wood. BioResoures 8(1): 182-188.

\author{
Xin You Liu*, Xin Wei Tu, Mihaela Liu \\ Nanjing Forestry University \\ 1.Co-Innovation Center of Efficient Processing and Utilization \\ of Forest Resources \\ 2.College of Furnishing And Industrial Design \\ 3.Academy of Chinese Ecological Progress and Forestry Studies \\ LongPan No.I59, Nanjing 210037 \\ NANJING \\ China \\ *Corresponding author: liu.xinyou@njfu.edu.cn
}


